\section{GW23-e2675 GINSENOSIDE RG1 COUNTERACTS PM2.5-INDUCED CELL INJURY BY MODULATING INTRACELLULAR REDOX VIA NRF2 PATHWAY IN HUMAN UMBILICAL VEIN ENDOTHELIAL CELLS}

doi:10.1136/heartjnl-2012-302920a.63

Cai-ping Li, Ming-sheng Zhang, Gang Qin, Rui-zan Shi, Ji-yuan Lv, Cai-ping Li. Department of Cardiology, The Fist Clinical Hospital, Shanxi Medical University, Xinjiannanlu 56 Taiyuan Shanxi 030001, China

Objectives The purpose of this study was to explore the possible mechanism of the organic component of fine particle $\mathrm{PM}_{2.5^{-}}$ induced endothelial cell injury and the cytoprotective effects of the Rg1.

Methods After stimulation with $\mathrm{PM}_{2.5}$ and ginsenoside $\mathrm{Rg} 1$ for the indicated concentration $\left(\mathrm{PM}_{2.5}: 0-800 \mu \mathrm{g} / \mathrm{ml}, \mathrm{Rg} 1: 2.5-40 \mu \mathrm{g} / \mathrm{ml}\right)$, the cell viability of HUVECs were assessed by CCK-8 assay, the oxidative stress of HUVECs were assessed by ROS and MDA assay. Furthermore, the influence of $\mathrm{PM}_{2.5}$ and ginsenoside $\mathrm{Rg} 1$ on the expression of Nrf2, Keap1 and HO-1 was investigated by RT-PCR and Western blotting assays. The confocal microscopy was applied to observe the Nrf2 expression and nuclei translocation. Design and construct the short hairpin carrier direct against Nrf2, transfect cells with Lipofectamine2000, select the ShRNA, study the toxicity of $\mathrm{PM}_{2.5}(400 \mu \mathrm{g} / \mathrm{ml})$ with or without $\mathrm{Rg} 1(40 \mu \mathrm{g} / \mathrm{ml})$ after Nrf2 is interfered, assay the cell viability by CCK-8, measure the reactive oxygen species, the expression of $\mathrm{HO}-1$ protein.

Results $\mathrm{PM}_{2.5}$, at concentrations of 200,400 , and $800 \mu \mathrm{g} / \mathrm{ml}$, reduced HUVECs viability by $30.7 \pm 2.8 \%, 54.8 \pm 3.9 \%$ and 70.2 $\pm 2.8 \%$, respectively, and the $\mathrm{IC}_{50}$ value for $\mathrm{PM}_{2.5}$ to reduce HUVEC viability by $50 \%$ was $526.9 \mu \mathrm{g} / \mathrm{ml}$. Incubation for $48 \mathrm{~h}$ with Rg1 2.5, 10 and $40 \mu \mathrm{g} / \mathrm{ml}$ concentration-dependently antagonised the HUVECs viability decrease induced by $\mathrm{PM}_{2.5}$. Coincubation with $\operatorname{Rg} 12.5,10,40 \mu \mathrm{g} / \mathrm{ml}$, the $\mathrm{IC}_{50}$ of $\mathrm{PM}_{2.5}$ increased to $592.3,825.6$ and $1232.1 \mu \mathrm{g} / \mathrm{ml}$ respectively. $\mathrm{PM}_{2.5}$ dose-dependently stimulated oxidative stress generation in HUVECs. In addition to cell death, pretreatment with Rg1 could also significantly increase HO-1 mRNA and protein expression and decrease ROS level and MDA production. The green fluorescence intensities in control and HUVECs incubated with $\mathrm{PM}_{2.5} 800 \mu \mathrm{g} /$ $\mathrm{ml}$ were $148.0 \pm 4.0$ and $241.0 \pm 7.0(\mathrm{p}<0.05)$, respectively. $\mathrm{PM}_{2.5}$
$(100-800 \mu \mathrm{g} / \mathrm{ml})$ increases intracellular fluorescence in a concentration dependent manner. In presence of $\mathrm{Rg} 110 \mu \mathrm{g} / \mathrm{ml}$ and $40 \mu \mathrm{g} /$ $\mathrm{ml}$, the maximal green fluorescence intensity increases induced by $\mathrm{PM}_{2.5} 800 \mu \mathrm{g} / \mathrm{ml}$ were reduced to $216.0 \pm 2.0$ and $206.0 \pm 3.0$ $(\mathrm{p}<0.05)$ respectively. $\mathrm{MDA}$ concentration within control HUVECs was $0.87 \pm 0.07 \mathrm{nmol} / \mathrm{mg}$ protein. $\mathrm{PM}_{2.5}(100-800 \mu \mathrm{g} / \mathrm{ml})$ concentration dependently increased MDA with the maximum being $1.96 \pm 0.09 \mathrm{nmol} / \mathrm{mg}$ protein. Coculture with Rg1 (10 and $40 \mu \mathrm{g} / \mathrm{ml}$ ) decreased $\mathrm{PM}_{2.5}$-induced MDA production by $72.96 \%$ $(p<0.05)$ and $58.66 \%(p<0.05)$, respectively. Analysis using laser confocal microscopy revealed that $\mathrm{Rg} 1$ treatment led to a dramatic increase in the level of Nrf2. The ratio of cytoplasmic Nrf2 protein to nuclear Nrf2 protein was markedly reduced and reached maximum at $40 \mu \mathrm{g} / \mathrm{ml}$ (0.09) compared with that of the $\mathrm{PM}_{2.5}$ only (0.3) and control (0.4). However the Keap1 has no changed. When the RNA of Nrf2 was interfered, the HO-1 protein expression was decreased, the cell viability was descend by $39.1 \%$ $\left(\mathrm{PM}_{2.5} 400 \mu \mathrm{g} / \mathrm{ml}\right), 36.0 \%\left(\mathrm{PM}_{2.5} 400 \mu \mathrm{g} / \mathrm{ml}\right.$ with $\left.\mathrm{Rg} 1\right)$, and $\mathrm{ROS}$ was increased by $40.2 \%\left(\mathrm{PM}_{2.5} 400 \mu \mathrm{g} / \mathrm{ml}\right), 38.0 \%\left(\mathrm{PM}_{2.5} 400 \mu \mathrm{g} / \mathrm{ml}\right.$ with Rg1), compared with negative control group, and they both are of significant difference in statistics. The protective effect of Rg1 on cells was decreased.

Conclusions our results suggest that Nrf2 was activated and protect the cells from cytotoxicity caused by the organic component of fine particle $\mathrm{PM}_{2.5}$ and $\mathrm{Rg} 1$ can attenuate $\mathrm{PM}_{2.5}$-induced cell damage by augmenting the cellular antioxidant defense including higher HO-1 expression. In addition, Rg1 also promoted nuclear translocation of Nrf2. which put new evidence on the cardiovascular-protective mechanism of $\mathrm{Rg} 1$ against the oxidative stress of $\mathrm{PM}_{2.5}$ in Nrf2 pathway in HUVECs. 